\title{
Impacts of drought on tree mortality and growth in a mixed hardwood forest
}

\author{
Elliott, K.J. \& Swank, W.T. \\ USDA Forest Service, Southeastern Forest Experiment Station, Coweeta Hydrologic Laboratory, \\ Otto, NC, 28763, USA; Tel. + $17045242128 ;$ Fax +17043696767
}

\begin{abstract}
The tree and shrub species on a 16-hawatershed in the Coweeta Basin were sampled in 1984 and again in 1991 to determine the effects of drought on tree species composition and basal area growth. Mortality and radial growth were determined for tree species within three community types that represent a moisture gradient from moist to dry: covehardwoods > mixed-oak > oak-pine. Tree mortality from 1984 to 1991 was $20 \%$ and $23 \%$ in the cove-hardwoods and mixed-oak communities, respectively, compared to only $12 \%$ in the oak-pine type. With the exception of Oxydendrum arboreum and Robinia pseudoacacia, the oaks had higher percentage mortality than any other genus; Quercus velutina had $29 \%, 37 \%$, and $20 \%$ mortality in the cove-hardwoods, mixed-oak, and oak-pine types, respectively; Quercusprinus had $23 \%$ mortality in the mixed-oak type; Quercus coccinea had $36 \%$ mortality in the mixed-oak type; and Quercus marilandica had $27 \%$ mortality in the oak-pine type. Mortality occurred mostly in the small-size class individuals $(<10 \mathrm{~cm}$ in diameter) for all species, suggesting that thinning was still an important process contributing to mortality $29 \mathrm{yr}$ after clearcutting. Although growth of Liriodendron tulipiferawas much higher than growth of either Quercus prinus or Quercus coccinea, growth in Liriodendron was significantly reduced by the 1985-88 drought and no growth reduction was observed for these two dominant Quercus species during the same time period.
\end{abstract}

Keywords: Coweeta Basin; Disturbance; Forest dynamics; Liriodendron tulipifera; Quercus; Southern Appalachians.

Nomenclature: Brown \& Kirkman (1990).

\section{Introduction}

Disturbances such as fire, drought, and harvesting can influence the composition and structure of forest communities. Changes in tree composition and structure due to drought in the early stage of stand development may be difficult to understand because of the complex relationships associated with differential sensitivity to drought among species, competitive interactions, and within-site variability. However, long-term data sets including climate and vegetation inventories may provide some insight as to how drought influences tree mortality and growth in typically high rainfall regions of Southern Appalachian forests.

Watershed 13 (WS13), a mixed hardwood forest in the Coweeta Basin, was clearcut in 1939-1940 and again in 1962 to determine the effects of vegetation manipulation on the quantity and timing of streamflow (Swank \& Helvy 1970; Swank et al. 1988). Streamflow increased $360 \mathrm{~mm}$ the first year after cutting and was still slightly above pretreatment levels for $23 \mathrm{yr}$ after cutting. After the second clearcut. annual water yield increased by $380 \mathrm{~mm}$ the first year, but returned to pretreatment levels after just $16 \mathrm{yr}$ of forest regrowth (Swank \& Helvey 1970). These disturbances and changes in watershed hydrology have allowed mesic-site species such as Liriodendron tulipifera and Betula lenta to invade drier sites dominated by oaks (Quercus spp.) (Parker \& Swank 1982), probably in response to elevated light, soil moisture and nutrients. However, as regrowth continues, these mesic species could be at a competitive disadvantage against species that are better adapted to lower resource levels. For example, as soil moisture returns to predisturbance levels, the ridge and slope sites may become too dry to support mesic species.

Parker \& Swank (1982) suggested that reestablishment of the soil moisture gradient or a more abrupt event such as drought, could restore preclearcut species distributions. Thus, it was hypothesized that mesic species such as Liriodendron tulipifera and Betula lenta which expanded their range onto slopes after the 1962 clearcut, would decline on these sites in a prolonged drought (Leopold 1984). The influence of a gradual hydrologic shift on forest spatial patterns could cause both competitive and gradient stress to a variety of species, but Leopold \& Parker (1985) and Leopold et al. (1985) concluded that growth data for major tree species during the first 21 yr after the second clearcut did not show that species and community distributions returned to precut patterns. Leopold et al. (1985) also suggested that $L$. 
tulipifera would continue to dominate the slope areas in WS13 unless a severe disturbance such as a drought occurred.

Historically, severe droughts have caused high tree mortality in the Southern USA (Hursh \& Haasis 1931; Tainter et al. 1984; Stringer et al. 1989; Starkey et al. 1989). After the 1984 vegetation inventory conducted by Leopold (1984), a major drought was recorded from 1985-1988 in the Coweeta Basin (Swift \& Blood 1987). It was the most severe drought on record in terms of duration and accumulated precipitation deficit. For this period, precipitation averaged $136.4 \mathrm{~cm}$, which was $24 \%$ below normal. At the peak of the drought in 1986, total precipitation for the year was $123.9 \mathrm{~cm}, 31 \%$ below normal (unpubl. data, USDA Forest Service). The return interval for this event, based on streamflow, was estimated to be $233 \mathrm{yr}$ (Swift et al. 1989). Clinton et al. (1993) showed an increase in canopy gap formation in the Coweeta Basin during the 1985-88 drought.

The purpose of this research was: (1) to assess the impacts of drought on tree mortality and growth, and (2) to determine whether mesic tree species such as Liriodendron tulipifera and Betula lenta have returned to their predisturbance locations (prior to the 1939-40 clearcut) where they were restricted to the mesic covehardwoods forest.

\section{Methods}

\section{Site description}

The Coweeta Basin, a 16.1 ha-northeast-facing catchment, is located in southwestern North Carolina, $35^{\circ} 04^{\prime}$ $30^{\prime \prime} \mathrm{N}, 83^{\circ} 26^{\prime} \mathrm{W}$. Elevations range from 724 to $853 \mathrm{~m}$, mean land slope is $51 \%$, and mean annual precipitation is ca. $1800 \mathrm{~mm}$. Mean annual temperature is $12.6^{\circ} \mathrm{C}$ and average temperature ranges from $6.7^{\circ} \mathrm{C}$ in the dormant season to $18.5^{\circ} \mathrm{C}$ in the growing season. Four soil types are present on the watershed: (1) Cullasaja-Tuckasegee (cove bottoms), loamy-skeletal/coarse-loamy, mixed, mesic Typic Haplumbrepts; (2) Edneyville-Chestnut (lower slopes), coarse loamy, mixed mesic Typic Dystrochrepts; (3) Plott (middle slopes), coarse loamy, mixed, mesic Typic Haplumbrepts; and (4) Evard-Cowee (upper slopes), fine-loamy, mixed, mesic Typic Hapludults.

All trees and shrubs on the entire drainage were felled withachainsaw and scattered by hand in 1939-40 and again in late 1962. No timber was removed after either clearcut and soil disturbance was minimal. No other treatments have occurred since 1934.

Community types were determined on aerial photos and verified in the field (Leopold \& Parker 1985). The three community types represent a moisture gradient from mesic to xeric; cove-hardwoods $>$ mixed-oak $>$ oak-pine. Leopold \& Parker (1985) established a soil moisture gradient from soil moisture samples taken in June, July, and August, 1983. Other studies within the Coweeta Basin have verified this gradient in soil moisture which increases from dry ridge and midslope topographic positions to moist cove bottoms (Helvey et al. 1972; Yeakley 1993). During periods of short-term drought (ca. 20-day summer drought), the difference in soil moisture between midslope and ridge locations becomes greater.

\section{Plot measurements}

In the summer of $1981,2610 \mathrm{~m} \times 20 \mathrm{~m}$ permanent plots were systematically located over WS13 to ensure adequate representation of the vegetation in three community types: cove-hardwoods $(n=9)$, mixed-oak $(n=$ $11)$, and oak-pine $(n=6)$. However, within a community type, plots were randomly located. The sample size was greatest in the mixed-oak type, less in the covehardwoods and least in the oak-pine type due to the proportional area occupied by each community type in the watershed. In 1984, basal area and density of the two dominant shrubs (Kalmialatifolia and Rhododendron maximum) were measured in all 26 plots (Leopold et al. 1985). All trees $>5.0 \mathrm{~cm}$ diameter at breast height $(\mathrm{DBH}$; $1.37 \mathrm{~m}$ aboveground) were tagged in the 26 plots. All permanent plots were relocated andremeasured in 1991. DBH was measured to the nearest $0.1 \mathrm{~cm}$ on all trees $>5.0 \mathrm{~cm}$. Basal area of the shrub layer (stems $0.5-5.0 \mathrm{~m}$ height) was calculated by measuring the diameter of stems $>0.5 \mathrm{~cm}$ at $15 \mathrm{~cm}$ aboveground on $3.0 \mathrm{~m} \times 5.0 \mathrm{~m}$ subplots randomly located within each of the 26 permanent plots. In addition to the tree and shrub measurements, densities of tree saplings $<0.5 \mathrm{~m}$ height were included in the 1991 inventory. Four $1.0 \mathrm{~m}^{2}$ subplots were located $2.0 \mathrm{~m}$ from each plot comer at a $45^{\circ}$ angle within each permanent plot to estimate density of tree saplings. To determine annual radial growth of trees, one core from three canopy dominants or codominants per plot was taken in each of the 26 plots. Cores were extracted at about $30-40 \mathrm{~cm}$ aboveground, parallel to the slope when possible. Growth was determined for the past 15 yr (1976-1991) with an Incremental Measuring Machine (Fred C. Henson Company, Mission Viejo, CA) to overlap Leopold's (1984) growth measurements.

\section{Statistical analysis}

Analysis of variance was used to determine significant differences in percentage mortality, ingrowth, and sapling density among cove-hardwoods, mixed-oak, and oak-pine community types (PROCGLM, Anon. 1987). 
Where analysis of variance was significant, a Tukey's StudentizedRange test was used to separate means. We used a repeated measures analysis of variance to examine the effect of year and species on annual radial growth of the three most common tree species in WS13 (Liriodendron tulipifera, Quercus coccinea, and $Q$. prinus). The effect of year and location (cove or midslope) was tested only on $L$. tulipifera radial growth because it was the only species of the three that occurred in both cove and midslope locations (PROC GLM, Anon. 1987). If an overall significant $F$-value was found, tests for significant changes between adjacent years were made using the appropriate orthogonal contrasts to determine where increases or decreases in radial growth took place. Significance was determined at an $\alpha$-level of 0.05 .

\section{Results}

Liriodendron tulipifera dominated the cove-hardwoods community, accounting for $>85 \%$ of total basal area and $40 \%$ of stem numbers in 1991 (Table 1). L. tulipifera, Acer rubrum, and Betula lenta constituted $77 \%$ of the importance value in the cove-hardwoods community type. Quercus prinus was the dominant species in the mixed-oak community, comprising $>40 \%$ of the total basal area and $33 \%$ of stem numbers. A. rubrum was the second most important species in the cove-hardwoods and mixed-oak community types and the third most important in the oak-pine community in 1991 (Table 1). Its importance values in the three communities were 11.9,20.7, and 16.9, respectively. Pinus rigida and $Q$. marilandica occurred only in the oak-pine community in 1991.

Rhododendron maximum and Kalmia latifoliawere the two dominant shrubs within WS13. R. maximum had higher density and basal area in the mixed-oak community than either the cove-hardwoods or oak-pine communities (Table 2). Although $K$. latifolia was present in all three community types, it had much higher density and basal area in the oak-pine type than either the covehardwoods or mixed-oak. The rank of communities in terms of shrub basal area was mixed oak > oak-pine > cove-hardwoods (Table 2).

Although there were no significant differences in density of tree saplings among the community types, the oak-pine community had significantly $\left(p=0.05, \mathrm{~F}_{2,23}=\right.$ 3.32) higher density of oak saplings (Q. prinus, $Q$. coccinea, $Q$. rubra, and $Q$. velutina) than either the covehardwoods or the mixed-oak types in WS13 for 1991. Sassafras albidum, A. rubrum, and L. tulipifera constituted $70 \%$ of the tree sapling density in the covehardwoods community. A. rubrum, $Q$. coccinea, and A. pensylvanicum constituted $71 \%$ of the tree sapling
Table 1. Density, basal area, and importance value (relative density + relative basal area/2) of tree species of the three community types in Watershed 13 measured in 1984 and 1991.

\begin{tabular}{|c|c|c|c|c|c|c|}
\hline \multirow[t]{2}{*}{ Species } & \multicolumn{2}{|c|}{$\begin{array}{c}\text { Density } \\
\text { (stems/ha) }\end{array}$} & \multicolumn{2}{|c|}{$\begin{array}{c}\text { Basal area } \\
\left(\mathrm{m}^{2} / \mathrm{ha}\right)\end{array}$} & \multicolumn{2}{|c|}{$\begin{array}{l}\text { Importance } \\
\text { value }\end{array}$} \\
\hline & $1984^{1}$ & 1991 & 1984 & 1991 & 1984 & 1991 \\
\hline \multicolumn{7}{|l|}{ Cove-hardwoods type } \\
\hline Liriodendron tulipifera & 911 & 6951 & 19.44 & 25.14 & 58.0 & 57.5 \\
\hline Acer rubrum & 372 & 316 & 1.63 & 1.97 & 11.6 & 11.9 \\
\hline Betula lenta & 188 & 188 & 1.22 & 1.79 & 6.6 & 8.0 \\
\hline Comusflorida & 139 & 111 & 0.38 & 0.38 & 3.9 & 3.7 \\
\hline Oxydendrum arboreum & 139 & 100 & 0.64 & 0.51 & 4.4 & 3.6 \\
\hline Quercus velutina & 133 & 94 & 1.05 & 1.16 & 5.1 & 4.4 \\
\hline Robinia pseudoacacia & 67 & 55 & 0.90 & 1.06 & 3.2 & 3.2 \\
\hline Carya spp. & 72 & 56 & 0.21 & 0.22 & 2.0 & 1.9 \\
\hline Sassafras albidum & 61 & 50 & 0.27 & 0.34 & 1.9 & 1.9 \\
\hline Fraxinus americana & 28 & 22 & 0.12 & 0.14 & 0.9 & 0.8 \\
\hline Hamamelis virginiana & 22 & 22 & 0.08 & 0.09 & 0.7 & 0.8 \\
\hline Tilia heterophvlla & 22 & 17 & 0.20 & 0.28 & 0.9 & 0.9 \\
\hline Nyssa sylvatica & 11 & 11 & 0.03 & 0.05 & 0.3 & 0.4 \\
\hline Other species ${ }^{3}$ & 24 & 18 & 0.15 & 0.15 & 0.9 & 0.7 \\
\hline Total & 2189 & 1755 & 26.31 & 33.28 & & \\
\hline Ingrowth & & 39 & & & & \\
\hline Mortality² & & $511(23 \%$ & & & & \\
\hline Net Change & & $-20 \%$ & & $+26 \%$ & & \\
\hline \multicolumn{7}{|l|}{ Mixed-oak type } \\
\hline Quercus prinus & 854 & 654 & 7.58 & 10.08 & 37.5 & 36.6 \\
\hline Acer rubrum & 509 & 491 & 3.10 & 4.20 & 18.6 & 20.7 \\
\hline Quercus coccinea & 227 & 146 & 1.90 & 2.42 & 9.7 & 8.5 \\
\hline Oxydendrum arboreum & 177 & 114 & 0.96 & 0.83 & 6.2 & 4.5 \\
\hline Quercus velutina & 159 & 100 & 1.16 & 1.47 & 6.3 & 5.4 \\
\hline Cornus florida & 77 & 96 & 0.19 & 0.25 & 2.1 & 2.9 \\
\hline Carya spp. & 82 & 82 & 0.28 & 0.33 & 2.4 & 2.7 \\
\hline Liriodendron tulipifera & 72 & 68 & 1.74 & 2.63 & 6.1 & 7.0 \\
\hline Betula lenta & 68 & 68 & 0.55 & 0.89 & 2.8 & 3.5 \\
\hline Amelanchier arborea & 54 & 54 & 0.18 & 0.22 & 1.6 & 1.8 \\
\hline Robinia pseudoacacia & 32 & 14 & 0.34 & 0.23 & 1.6 & 0.8 \\
\hline Magnolia acuminata & 32 & 32 & 0.76 & 1.13 & 2.6 & 3.1 \\
\hline Hamamelis virginiana & 32 & 27 & 0.09 & 0.09 & 0.9 & 0.8 \\
\hline Sassafras albidum & 23 & 23 & 0.09 & 0.14 & 0.7 & 0.8 \\
\hline Nyssa sylvatica & 14 & 4 & 0.03 & 0.01 & 0.4 & 0.1 \\
\hline Other species ${ }^{3}$ & 13 & 9 & 0.10 & 0.16 & 0.5 & 0.5 \\
\hline Total & 2425 & 1982 & 19.05 & 25.08 & & \\
\hline Ingrow & & 45 & & & & \\
\hline Mortality ${ }^{2}$ & & $491(20 \%$ & & & & \\
\hline Net Change & & $-18 \%$ & & $+32 \%$ & & \\
\hline \multicolumn{7}{|l|}{ Oak-pine type } \\
\hline Quercus coccinea & 475 & 458 & 2.85 & 4.46 & 22.6 & 24.1 \\
\hline Acer rubrt & 358 & 442 & 1.34 & 2.18 & 13.7 & 16.9 \\
\hline Quercus & 358 & 333 & 2.39 & 3.54 & 18.1 & 18.4 \\
\hline Q. marilandica & 333 & 242 & 1.42 & 1.34 & 13.5 & 9.7 \\
\hline Amelanchier arborea & 167 & 175 & 0.54 & 0.93 & 6.0 & 6.9 \\
\hline Quercus velutina & 125 & 100 & 0.97 & 1.44 & 6.9 & 6.6 \\
\hline Pinus rigida & 116 & 116 & 1.30 & 2.10 & 8.0 & 9.0 \\
\hline Oxydendrum arboreum & 100 & 92 & 0.49 & 0.58 & 4.3 & 3.9 \\
\hline Robinia pseudoacacia & 83 & 58 & 0.50 & 0.51 & 4.0 & 2.9 \\
\hline Symplocos tinctoria & 34 & 50 & 0.08 & 0.17 & 1.2 & 1.7 \\
\hline Other species ${ }^{3}$ & 48 & 56 & 0.21 & 0.45 & 2.0 & 2.3 \\
\hline Total & 2197 & 2122 & 12.09 & 16.76 & & \\
\hline Ingrow & & 183 & & & & \\
\hline Mortality ${ }^{2}$ & & $258(12 \%$ & & & & \\
\hline Net Change & & $-4 \%$ & & $+39 \%$ & & \\
\hline
\end{tabular}

1 Data collected in 1984 were provided by Dr. Donald J. Leopold, summary published in Leopold (1984). ${ }^{2}$ Mortality is based on death of permanently marked trees. ${ }^{3}$ Other less frequent species were Nyssa sylvatica, Quercus alba, Q. rubra, Acer pensylvanicum, Diospyros virginiana, Castanea dentata. 
Table 2. Density (stems $/ \mathrm{ha}$ ) and basal area $\left(\mathrm{m}^{2} / \mathrm{ha}\right)$ of trees and shrubs (0.5-5.0 $\mathrm{m}$ tall) found in the shrub layer in the three community types of Watershed 13. Coweeta Basin.

\begin{tabular}{|c|c|c|c|c|c|c|}
\hline \multirow[b]{2}{*}{ Species } & \multicolumn{2}{|c|}{ Cove-hardwoods } & \multicolumn{2}{|c|}{ Mixed-oak } & \multicolumn{2}{|c|}{ Oak-pine } \\
\hline & Density & Basal area & Density & Basal area & Density & Basal area \\
\hline Rhododendron maximum & 1555 & 1.281 & 5030 & 5.154 & - & - \\
\hline Kalmia latifolia & 1,778 & 0.920 & 3394 & 2.019 & 12556 & 4.952 \\
\hline Hamamelis virginiana & 444 & 0.377 & - & & - & \\
\hline Calycanthus floridus & & - & 61 & $0.0 \overline{03}$ & 333 & $0 . \overline{112}$ \\
\hline Gavlussacia ursina & - & - & 242 & 0.004 & 2556 & 0.201 \\
\hline Cornus florida & $2 \overline{22}$ & 0.093 & 182 & 0.074 & - & - \\
\hline Pyrularia pubera & 148 & 0.005 & 182 & 0.006 & 22 & 0.009 \\
\hline Euonymus americanus & & - & 121 & 0.030 & - & \\
\hline Vitisaestivalis & $\overline{74}$ & 0.034 & - & & - & $\bar{Z}$ \\
\hline Symplocos tinctoria & - & - & - & 二 & 22 & 0.017 \\
\hline Total & 4221 & 2.708 & 9212 & 7.290 & 15889 & 5.291 \\
\hline
\end{tabular}

density in the mixed-oak type. In the oak-pine type, A. rubrum, $Q$. coccinea, and $Q$.prinus comprised $88 \%$ of the sapling density. $Q$. velutina and $Q$. rubra were the only oaks to have saplings in the cove-hardwoods community (Table 3).

The oak-pine type had significantly $\left(p=0.026, \mathrm{~F}_{2.23}\right.$ $=4.22)$ lower percentage mortality and significantly $(p$ $-0.006, F_{23}=6.46$ ) higher ingrowth than either the cove-hardwoods or mixed-oak types, but there were no significant differences between the mixed-oak and covehardwoods types. Although the net change in basal area from 1984 to 1991 was signficantly $\left(p=0.004, \mathrm{~F}_{2,23}=\right.$ 6.99) higher in the oak-pine type than in the covehardwoods, total basal area in the oak-pine type was only half that of the cove-hardwoods community (Table

Table 3. Density (number/ha) of tree saplings ( $<0.5 \mathrm{~m}$ tall) found in three community types in Watershed 13 , Coweeta Basin.

\begin{tabular}{lrrr}
\hline Tree seedlings & $\begin{array}{c}\text { Cove } \\
\text {-hardwoods }\end{array}$ & Mixed-oak & Oak-pine \\
\hline Cornusflorida & 1390 & 230 & 0 \\
Liriodendron tulipifera & 4160 & 0 & 0 \\
Acer pensylvanicum & 0 & 1360 & 0 \\
Sassafras albidum & 1110 & 460 & 0 \\
Carya spp. & 280 & 0 & 0 \\
Amelanchier arborea & 1670 & 460 & 0 \\
Acer rubrum & 6670 & 3180 & 7500 \\
Quercus rubra & 830 & 0 & 1250 \\
Oxydendrum arboreum & 280 & 680 & 0 \\
Robinia pseudoacacia & 0 & 230 & 0 \\
Nyssa sylvatica & 0 & 230 & 0 \\
Quercus velutina & 280 & 460 & 830 \\
Q. coccinea & 280 & 0 & 2500 \\
Q.prinus & 0 & 2730 & 5400 \\
Tsuga canadensis & 0 & 230 & 0 \\
Total Density & 16960 & 10250 & 17480 \\
\hline
\end{tabular}

1). Mortality from 1984 to 1991 was $20 \%$ and $23 \%$ in the cove-hardwoods and mixed-oak communities, respectively, but only $12 \%$ in the oak-pine type (Table 1 ). Ingrowth was about four times higher in the oak-pine type than the other community types, suggesting that recruitment of new individuals into the overstory was still an important process in the oak-pine type. After Oxydendrumarboreum and Robinia pseudoacacia, the oak species had the highest mortality; Quercus velutina had $29 \%, 37 \%$, and $20 \%$ mortality in the covehardwoods, mixed-oak, and oak-pine types, respectively; Q. prinus had $23 \%$ mortality in the mixed-oak type; $Q$. coccinea had $36 \%$ mortality in the mixed-oak type; and Q. marilandica had $27 \%$ mortality in the oak-pine type. Mortality of $L$. tulipiferavas $25 \%$ in the cove-hardwoods but only $6 \%$ in the mixed-oak type (Table 4 ).

Mortality was highest in the small-diameter size classes $(<10 \mathrm{~cm})$ for all species combined (Fig. 1) and for individual species (Table 4). With the exception of $O$. arboreum, mortality was more than twice as high in the $5.0-10.0 \mathrm{~cm}$ size class than in the $>10 \mathrm{~cm}$ size class for all species (Table 4). Because WS13 is a relatively young forest, for many of the species there were no stems larger than $10.0 \mathrm{~cm} \mathrm{DBH}$. A reduction of stems in the small size classes $(<12.5 \mathrm{~cm})$ in 1991 compared to 1984 in the cove-hardwoods and mixed-oak communities was mostly due to high mortality. However, in the oak-pine type, density of the small size classes $(<12.5 \mathrm{~cm}$ ) was almost equal in 1991 and 1984 (Fig. 1). There was only a net loss of $4 \%$ in the total number of stems because mortality and ingrowth were well balanced (Table 1).

Radial growth ofL. tulipifera was about $3.2-3.4 \mathrm{~mm} /$ yr per tree from 1978 to 1985 . It decreased significantly $(p<0.01)$ in 1986 through 1988 to about $2.0 \mathrm{~mm} / \mathrm{yr} /$ tree. After the drought, radial growth again rose to 2.8 $2.9 \mathrm{~mm} / \mathrm{yr} /$ tree (Fig. 2). By contrast, average radial 
Table 4. Percentage mortality from 1984 to 1991 of tree species by diameter size class for the three community types in Watershed 13, Coweeta Basin. Values in parentheses are total number of live trees in the sample plots for each community type (covehardwoods, $n=9$; mixed-oak, $n=11$; oak-pine, $n=6$ ) in 1984 .

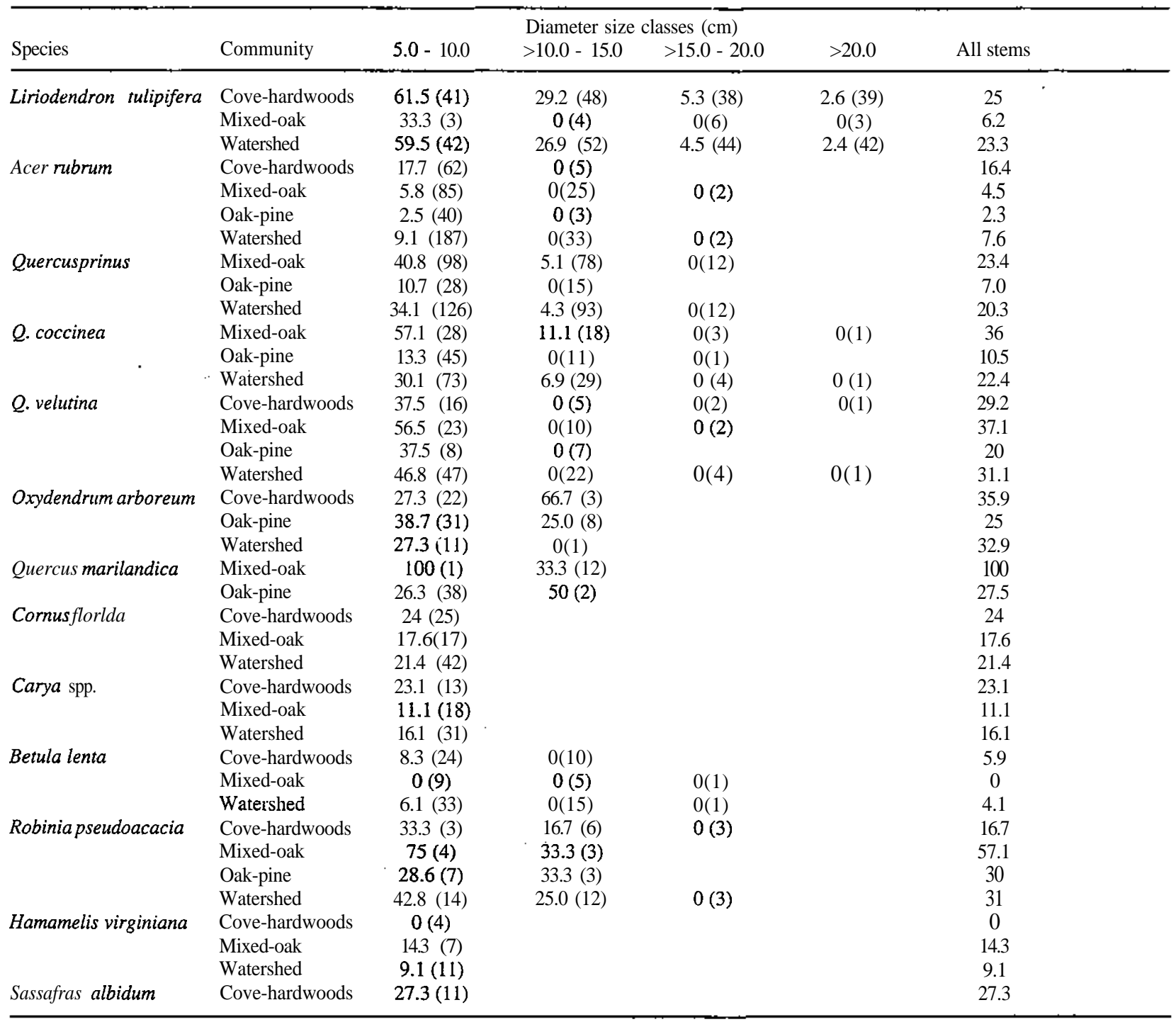

growth of the two dominant oak species, $Q$. prinus and $Q$. coccinea, did not significantly decrease during the 1985-88 drought (Fig. 2). However, radial growth was significantly lower $(p<0.01)$ for the oaks than for L. tulipifera (Fig. 2). In addition, radial growth of $L$. <tulipifera was not significantly greater in the mesic cove than on the drier midslope plots (Fig. 3).

\section{Discussion}

The expected trend in differential mortality between the mesic species and the more xeric species due to the
1985-88 drought did not occur in WS13. Mortality was as high for oaks, which occur naturally on the more xeric sites, as for L. tulipifera, which dominates mesic sites and is a minor component on xeric sites. Although $22 \%$ of the stems in WS13 died between 1984 and 1991, $92 \%$ of the L. tulipifera stems that died were stump sprouts and there was much higher mortality in the smaller size classes in both the cove-hardwoods and mixed-oak communities, suggesting that the mortality was due to thinning rather than drought. In addition, no mortality was recorded for Betula lenta, another of the species characteristic of mesic cove sites. Mortality was significantly lower in the oak-pine community than 

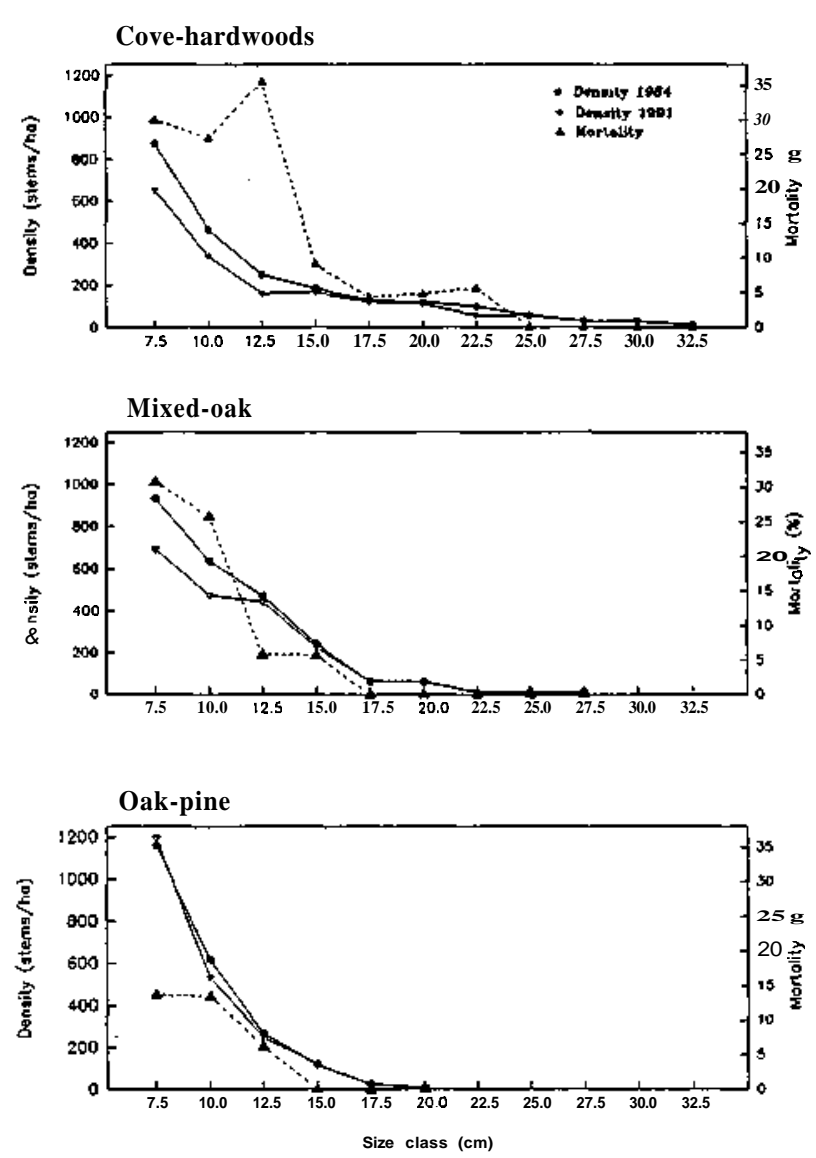

Fig. 1. Density and percentage mortality by diameter size class of all species combined in the cove-hardwoods, mixed-oak, and oak pine community types within Watershed 13, Coweeta Basin.

either the mixed-oak or cove-hardwoods communities. In other sections of the Coweeta Basin, significant mortality of Pinusrigida has occurred due to a combination of drought and subsequent attack by the southern pine beetle (Dendroctonus frontalis Zimmerman) (Smith 1991). However, in WS13 there was no mortality recorded for this species.

In previous inventories in WS13, density was reduced by $32 \%$ between ages 8 to $13 \mathrm{yr}$ andby $33 \%$ from 13 to $23 \mathrm{yr}$ after the first clearcut (1939-40). After the second clearcut (1962), density was reduced by $51 \%$ from 7-14 yr after cutting and by 50\% from 14-21 yr after cutting (Leopold et al. 1985). Between 1984 and 1991, reduction in density at the watershed level was only $20 \%$, suggesting that by 1991, $29 \mathrm{yr}$ after the second clearcut, percentage reduction in density was much lower than in the previous inventories. Although inventories prior to 1981 were not made on the same plots over the 50+ year period and mortality and ingrowth cannot be compared directly, the large reduc- tions in density early in stand development suggest that mortality due to thinning slowed down substantially by 1991. In addition, prior to the drought in 1984 total watershed density (2330 stems/ha) was already lower than the density in 1934 prior to clearcutting (2632 stems/ha) (Leopold et al. 1985).

Although much of the mortality may be attributed to self-thinning of suppressed individuals within clumps, there was a significant reduction in growth of dominant and codominant $L$. tulipiferaduring the drought years. Radial growth of $L$. tulipifera was much higher than growth of either $Q$. prinus or $Q$. coccinea, but growth in L. tulipifera was significantly reduced during the drought between 1985-88. However, there was no difference in the pattern of growth reduction during the drought years between $L$. tulipifera in cove and midslope locations, suggesting that larger individuals may have been tapping deep soil moisture reserves. Yeakley (1993) found that deeper soil layers $(30-90 \mathrm{~cm}$ depth) have much less temporal variation in soil moisture during drought events than the shallower soil layers $(0-30 \mathrm{~cm}$ depth). No corresponding growth reduction was found in the two oak species because they apparently adjust their morphology and physiology in response to drought stress (McGraw et al. 1990; Abrams 1990; Abrams et al. 1990). Modifications in leaf morphology such as high stomatal density, thick leaves, and small guard cells provide a mechanism for greater water use efficiency (Abrams \& Kubiske 1990). In addition, deep roots, effective water transport, and osmotic and elastic adjustments are primary factors contributing to drought tolerance in oaks (Abrams 1990). Thus, oak species often exhibit higher photosynthetic rates and smaller decreases in photosynthetic rates with increasing soil and atmospheric drought than co-occurring tree species (Weber \& Gates 1990; Abrams et al. 1990; see Abrams 1990 for review). In contrast, $L$. tulipifera is quite sensitive to changes in water status (Roberts 1990).

Quercus species show poor survival under intact canopies due to the combination of low light and competition from understory shrubs such as Kalmia and Gaylussacia ursina in the oak-pine community and Rhododendron maximum in the mixed-oak community. Although $Q$. prinus had relatively high numbers of saplings in the mixed-oak and oak-pine communities, 2730 and 5400 saplings/ha, respectively (Table 3), there were no Quercus saplings found in the shrub layer (Table 4) and only a few individuals of $Q$. coccinea in the oak-pine community growing into the overstory layer. Day et al. (1988) also reported that $Q$. coccinea and $Q$. velutina had poor regeneration throughout the Coweeta Basin and suggested that these species may be declining. This pattern of oak establishment is similar to that found in other regions of the eastern USA (Parker et 


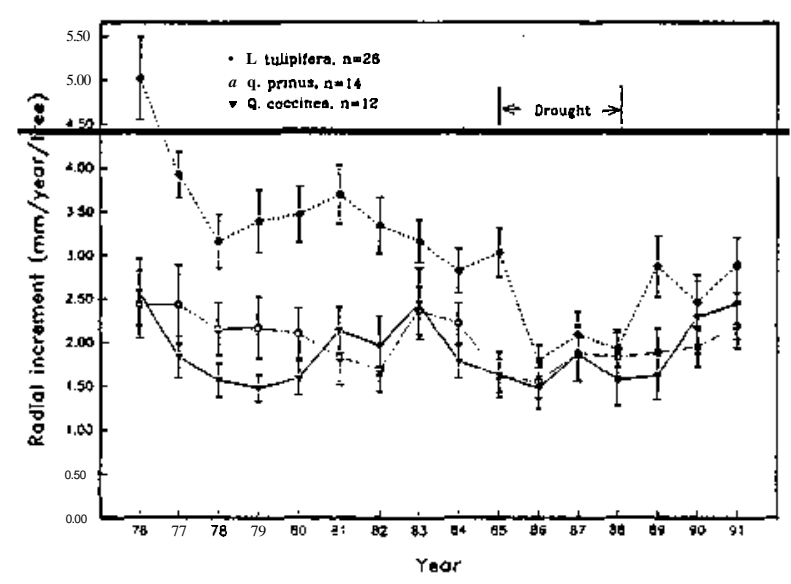

Fig. 2. Average basal area growth of Liriodendron tulipifera, Quercusprinus, and Q. coccinea in Watershed 13, Coweeta Basin, from 1976 to 1991.

al. 1985; Crow 1988; Lorimer 1989; Cho \& Boerner 1991; Ward 1992) as well as the Southern Appalachians (Stringer et al. 1989; Starkey et al. 1989). In addition, fire exclusion in the Southern Appalachians has favored the expansion of evergreen shrubs (Day \& Monk 1974; Monk et al. 1985; Lipscomb \& Nilsen 1990) and has reduced regeneration success of many Quercus species (Phillips \& Murdy 1985; Van Lear 1991) and Pinus rigida (Barden \& Woods 1976). Currently, areas occupied by shrubs are unfavorable for Quercus establishment. Thus, without the occurrence of canopy gaps small oak saplings can not reach pole size and may eventually die. However, as forests mature in WS13, additional mortality may create canopy gaps (Clinton et al. 1993) allowing for the successful establishment of Quercus and other shade intolerant species (Peet \& Loucks 1977).

\section{Conclusions}

A shift in species composition and community distribution to precut patterns has not occurred in WS13, even though a major drought was recorded in 19851988. Although Liriodendron tulipifercexhibited greater growth decline during the drought years than Quercus prinus and $Q$. coccinea, it did not have significantly higher levels of mortality than the other tree species in WS13. In undisturbed watersheds in the Coweeta Basin, tree mortality due to the 1985-88 drought was substantial. However, mortality in the relatively young forest of WS13 could be due to competition and its interaction with drought. Density-dependent mortality may have been less without the additional stress due to drought. In

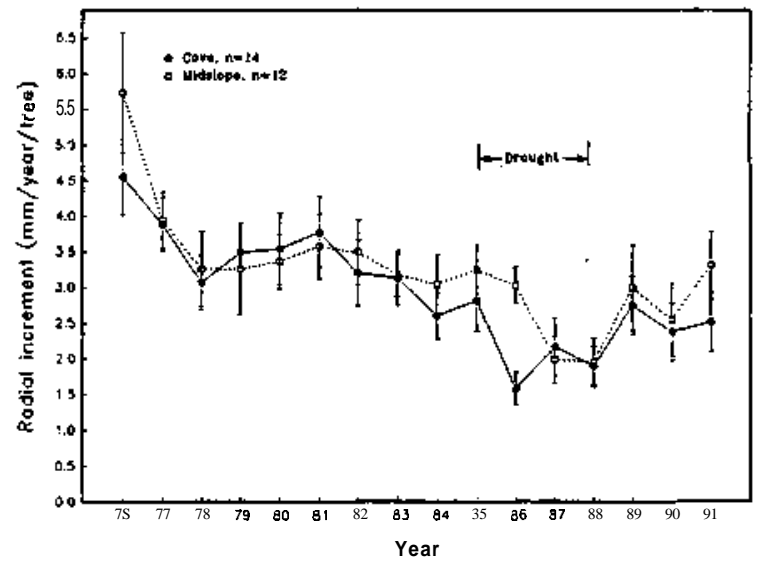

Fig. 3. Average basal area growth of Liriodendron tuiipifera on cove and midslope plots in Watershed 13, Coweeta Basin, from 1976 to 1991.

addition, during later stages of stand development older, less vigorous trees may be more severely impacted by drought stress. Thus, the greatest impact that can be attributed to the 1985-88 drought in WS13 was growth loss to L. tuiipifera rather than differential mortality between mesic and xeric species.

Acknowledgements. We thank James Buchanan and Lee Reynolds for the assistance in the field inventories and species identification. Dr. Donald Leopold, Dr. Edward Clebsch, and three anonymous reviewers provided helpful comments on this manuscript. Dr. Donald Leopold deserves special thanks for sharing his 1984 data.

\section{References}

Anon. 1987. SAS/STAT Guidefor Personal Computers, Version 6 Edition. SAS Institute Inc., Cary, NC.

Abrams, M.D. 1990. Adaptations and responses to drought in Quercus species of North America. Tree Physiol. 7: 227238.

Abrams, M.D. \& Kubiske, M.E. 1990. Leaf structural characteristics of 31 hardwood and conifer tree species in central Wisconsin: influence of light regime and shade tolerance rank. For. Ecol. Manage. 31: 245-253.

Abrams, M.D., Schultz, J.C. \& Kleiner, K.W. 1990. Ecophysiological responses in mesic versus xeric hardwood species to an early-season drought in central Pennsylvania. For. Sci. 36: 970-981.

Barden, L.S. \& Woods, F.W. 1976. Effects of fire on pine and pine-hardwood forests in the southern Appalachians. For. Sci. 22: 399-403.

Brown, C.L. \& L.K. Kirkman. 1990. Trees of Georgia and Adjacent States. Timber Press, Portland, OR. 
Cho, D.S. \& Boerner, R.E.J. 1991. Canopy disturbance patterns and regeneration of Quercus species in two Ohio old-growth forests. Vegetatio 93: 9-18.

Clinton, B.D., Boring, L.R. \& Swank, W.T. 1993. Characteristics of drought-induced canopy gaps in oak forests of the Coweeta Basin. Ecology 74: 1551-1558.

Crow, T.R. 1988. Reproductive mode and mechanisms for self-replacement of northern red oak (Quercus rubra) - A review. For. Sci. 34: 19-40.

Day, F.P. \& Monk, C.D. 1974. Vegetation patterns on a southern Appalachian watershed. Ecology 55: 1064-1074.

Day, F.P., Jr., Phillips, D.L. \& Monk, C.D. 1988. Forest communities and patterns. In: Swank, W.T., Crossley, D.A., Jr. (eds.) Ecological Studies 66, Forest hydrology and ecology at Coweeta, pp. 141-149. Springer-Verlag, New York, NY.

Helvey, J.D., Hewlett, J.D. \& Douglas, J.E. 1972. Predicting soil moisture in the southern Appalachians. Soil Sci. Am. Proc. 36 (6): 954-959.

Hursh, C.R. \& Haasis, F.W. 1931. Effects of 1925 summer drought on southern Appalachian hardwoods. Ecology 12: 380-386.

Leopold, D.J. 1984. Forest development, patterns and processes following successive clearcuts in the Southern Appalachians. Ph.D. diss., Purdue University, Lafayette, IA.

Leopold, D.J \& Parker, G.R. 1985. Vegetation patterns on a Southern Appalachian watershed after successive clearcuts. Castanea 50: 164-186.

Leopold, D.J., Parker, G.R. \& Swank, W.T. 1985. Forest development after successive clearcuts in the Southern Appalachians. For. Ecol. Manage. 13: 83-120.

Lipscomb, M.V. \& Nilsen, E.T. 1990. Environmental and physiological factors influencing the natural distribution of evergreen and deciduous ericaceous shrubs on northeast and southwest slopes of the S. Appalachian Mountains. I. Irradiance tolerance. Am. J. Bot. 77: 108-115.

Lorimer, C.G. 1989. The oak regeneration problem: new evidence on causes and possible solutions. Univ. Wis. For. Res. Analyses No. 8. Madison, WI.

McGraw, J.B., Gottschalk, K.W., Vavrek, M.C. \& Chester, A.L. 1990. Interactive effects of resource availabilities and defoliation on photosynthesis, growth, and mortality of red oak seedlings. Tree Physiol. 1: 247-254.

Monk, C.D., McGinty, D.T. \& Day, F.P. 1985. The ecological importance of Kalmia latifoliaand Rhododendron maximum in the deciduous forest of the southern Appalachians. Bull. Torrey Bot. Club 112: 193-197.

Parker, G.R. \& Swank, W.T. 1982. Tree species response to clear-cutting a Southern Appalachian watershed. Am. Midl. Nat. 108: 304-310.

Parker, G.R., Leopold, D.J. \& Eichenberger, J.K. 1985. Tree dynamics in an old-growth, deciduous forest. For. Ecol. Manage. 11: 31-57.

Peet, R.K. \& Loucks, O.L. 1977. A gradient analysis of southern Wisconsin forests. Ecology 58: 485-499.

Phillips, D.L. \& Murdy, W.H. 1985. Effects of rhododendron (Rhododendron maximum L.) on regeneration of southern Appalachian hardwoods. For. Sci. 31: 226-233.

Roberts, B.R. 1990. Physiological response of yellow-poplar seedlings to simulated acid rain, ozone fumigation, and drought. For. Ecol. Manage. 31: 215-224.

Smith, R.N. 1991. Species composition, stand structure, and woody detrital dynamics associated with pine mortality in the southern Appalachians. MSc Thesis, University of Georgia, Athens, GA.

Starkey,D.A., Oak, S.W., Ryan, G.W., Tainter, F.H., Redmond, C. \& Brown, H.D. 1989. Evaluation ofoak decline area in the south. USDA Forest Service, Forest Protection Report R8-TR 17.

Stringer, J.W., Kimmerer, T.W., Overstreet, J.C. \& Dunn, J.P. 1989. Oak mortality in eastern Kentucky. South. J. Appl. For. 13: 86-91.

Swank, W.T. \& Helvey, J.D. 1970. Reduction of streamflow increases following regrowth of clearcut hardwood forests. In: Symposium Results of Research on Representative and Experimental Basins. Proc. Wellington. Symp., Dec. 1970, Wellington, New Zealand, IAHS Publ. No. 96, pp. 346-360.

Swank, W.T., Swift, L.W., Jr. \& Douglass, J.E. 1988. Streamflow changes associated with forest cutting, species conversions, and natural disturbances. In: Swank, W.T. \& Crossley, D.A., Jr. (eds.) Ecological Studies 66, Forest hydrology and ecology at Coweeta, pp. 297-312. Springer-Verlag, New York, NY.

Swift, L.W. \& Blood, E.R. 1987. Drought impact research at two LTER sites. In: Southeastern drought symposium proceedings; 1987 March 4-5; Columbia, SC, pp. 102105 South Carolina State Climatology Office Publ. G-30; SC Water Resources Commission.

Swift, L.W., Waide, J.B. \& White, D.L. 1989. Refinements in the Z-T method of extreme value analysis for small watersheds. Sixth Conference on Applied Climatology, Charleston, SC American Meterological Society (publ.).

Tainter, F.H., Fraedrich, S.W. \& Benson, D.M. 1984. The effect of climate on growth, decline, and death of northern red oaks in the western North Carolina Nantahala mountains. Castanea 49: 127-137.

Van Lear, D.H. 1991. Fire and oak regeneration in the southern Appalachians. In: Nodvin, S.C. \& Waldrop, T.A. (eds.) Fire and the environment: ecological and cultural perspectives. Proc. Intern. Symp., March 20-24, Knoxville, TN. USDA For. Ser. Gen. Tech. Rep. SE-69, Southeastern Forest Experiment Station, Asheville, NC. pp. 15-21.

Ward, J.S. 1992. Response of woody regeneration to thinning mature upland oak stands in Connecticut, USA. For. Ecol. Manage. 49: 219-231.

Weber, J.A. \& Gates, D.M. 1990. Gas exchange in Quercus rubra (northern red oak) during drought: analysis of relations among photosynthesis, transpiration, and leaf conductance. Tree Physiol. 7: 215-225.

Yeakley, J.A. 1993. Hillslope soil moisture gradients in an upland forested watershed. $\mathrm{PhD}$. diss., University of Virginia, Charlottesville, VA.

Received 14 February 1993; Revision received 25 May 1993; Final revision received 16 December 1993; Accepted 17 December 1993. 